\title{
Discussion on Role of Forest to Control Agricultural Non-Point Source Pollution in Taihu Lake Basin-Based on Source-Sink Analysis
}

\author{
Jianfeng ZHANG ${ }^{1}$, Jingmin JIANG ${ }^{{ }^{*}}$, Zhijian ZHANG ${ }^{2}$, Qihua SHAN ${ }^{1}$, Guangcai CHEN ${ }^{1}$, Ying \\ WANG $^{1}$, Yonghui $\mathrm{XU}^{3}$, Harry WU ${ }^{4}$, Aljoy ABARQUEZ ${ }^{4}$ \\ ${ }^{1}$ Institute of Subtropical Forestry, Chinese Academy of Forestry, Fuyang, China \\ ${ }^{2}$ International Centers for Bamboo \& Rattan, Beijing, China \\ ${ }^{3}$ Yixing Forestry Technology Extension Station, Yixing, China \\ ${ }^{4}$ CSIRO Plant Industry, Canberra, Australia \\ E-mail:jmjiang6001@126.com
}

Received August 21, 2009; revised September 4, 2009; accepted September 12, 2009

\begin{abstract}
Taihu Lake is located at the center of Changjiang delta region, the Lake and its effluent rivers are important water sources for 40 million around inhabitants and rapidly increasing industrial factories in Shanghai, Jiangsu and Zhejiang. The pollutants originate mainly from acidy rain, home sewage of the vast number of inhabitants, livestock manure, agricultural fertilizers \& pesticides applied over fields in the drainage basin, and the industrial sewage. Due to the kinds of pollutants, the Lake water is getting highly eutrophic, with frequent blooms of blue-green algae. Compared with point-source pollutants, diffuse pollution is much complicated and difficult to control. Thus combating non-point pollution (NPP) is paid much great attention. Based on analysis on source-sink of NPP in Taihu Lake basin, it is concluded that the function of forests on NPP control is multiple and important by both source reduction and sink expansion. The primary objective of planting trees through constructing forested wetlands and establishing riparian forest buffers is to control soil \& water erosion, decrease agrochemicals application, and improve farming conditions in the region of Taihu Lake basin. Moreover forests help to intercept acidy rain, protect streambanks, uptake nutrients, hold up pollutants and provide habitat for wildlife.
\end{abstract}

Keywords: Non-Point Source Pollution, Riparian Forest Buffer Zone, Source-Sink, Taihu Lake

\section{Introduction}

The Taihu Lake basin has an area of $36500 \mathrm{~km}^{2}$, located in three provinces and one municipality. The percentage in Jiangsu, Zhejiang, Anhui provinces and Shanghai is $52 \%, 33.4 \%, 13.5 \%$ and $0.1 \%$ respectively. The water area in the lake basin accounts for $17.5 \%$ of the entire lake area [1]. The Lake has the multifunction of floodwater storage, irrigation, navigation, water supply, aquaculture, and tourism. It is the main drinking water source for 40 million residents for areas such as Wuxi and Suzhou and people in neighboring Shanghai and Zhejiang. The Lake also is famous for its abundant production of fishes and crabs, and the aquaculture farms on the coast that apply skillful techniques [2].

The region along Taihu basin was developed very earlier owing to the kind natural conditions (Table 1), which was called "Kingdom of fishing \& farming".

Also the vegetation resources were abundant there. Types of important forest (main species of trees): Pine forest (Pinus massoniana); bamboo forest (Phyllostachys pubescens); mixed evergreen-deciduous scrub. Types of important herbaceous vegetation: Swampy grassland of reeds and other emerged water plants on the lake shore and along water courses. Main kinds of crops: Rice (single or double cropping), wheat, rapeseed, tea, mulberry, fruit trees (peach, orange, loquat, myrica, plum, Japanese apricot (Prunus mume), jujube) [3].

In addition to supporting heavy boat traffic, Taihu provides some of the best known water-side scenery in China for domestic and foreign sightseeing visitors. Hence the urbanization level of the lake basin ranks the first in the entire country.

However, due to the excess consumption of resources 


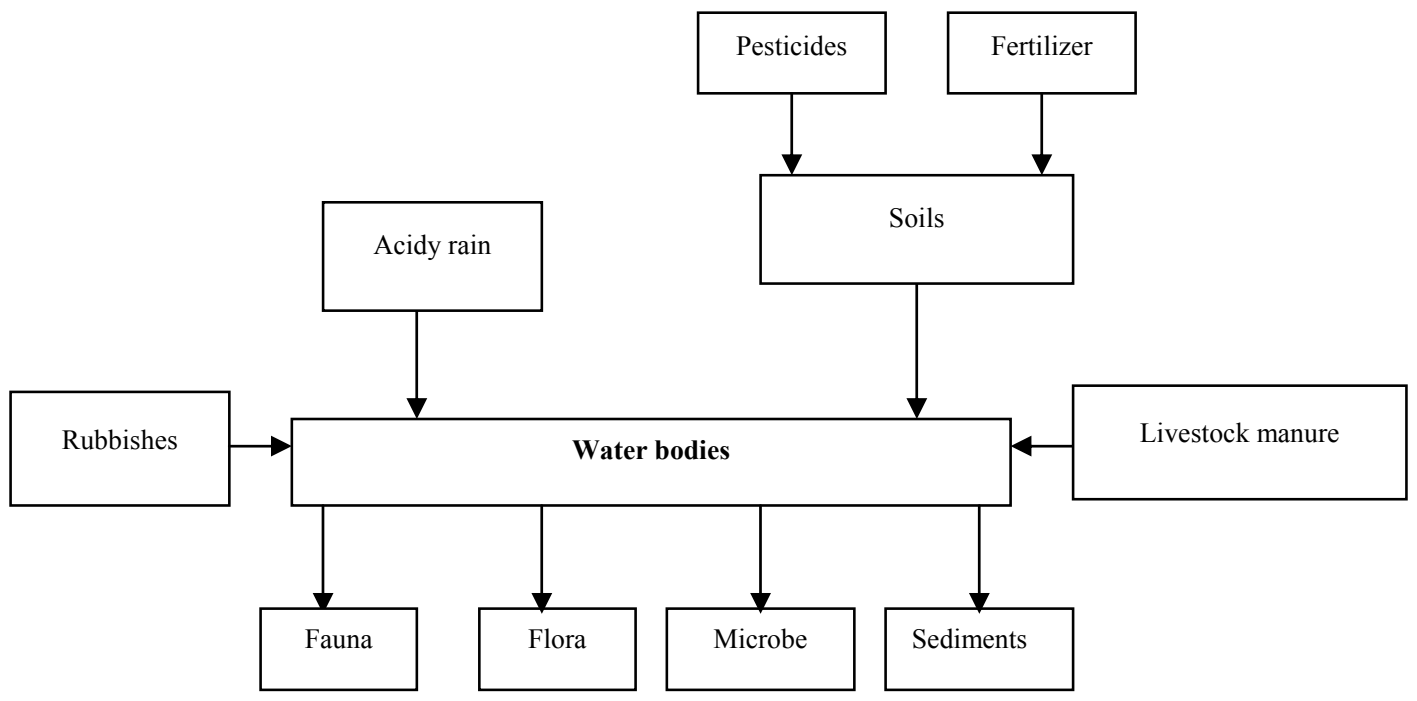

Figure 1. Source-sink of non-point agricultural pollution in Taihu lake basin.

Table 1. Natural conditions in Taihu basin.

Longitude: $\mathrm{E} 116^{\circ} 28^{\prime}--123^{\circ}$

Latitude: N $23^{\circ} 33^{\prime}--32^{\circ} 08^{\prime}$

Elevation (meters above sea level): 3.1-4.5 m above sea level

Rainfall:

Mean annual Rainfall (mm): $974 \mathrm{~mm}$

Months of Highest Rainfall: June $156 \mathrm{~mm}$

Months of Lowest Rainfall: January 38mm

Temperature:

Other notes on Rainfall (re: fog, snow, and/or other forms of precipitation): few snow; sometimes storm in summer

Mean Annual Temperature: $15.6^{\circ} \mathrm{C}$

Months of Highest Temperature: July $29.9^{\circ} \mathrm{C}$

Months of Lowest Temperature: January $2.9^{\circ} \mathrm{C}$

Other notes on Temperature: hot summer(June, July and August)

Soil:

Depth to parent material: $1-5 \mathrm{~m}$

$\mathrm{pH}: 6.2-8.0$

Colour: brown

Texture: sand-loam

Geological Origin: flooding

Other notes on Soil: in some parts paddy soil

Exposure to Sunlight: $2000 \mathrm{hr}$ annually

Terrain:

\author{
Slope Steepness (\% or degrees): plain area, $0-5^{0}$ \\ Drainage: not so heavy \\ Depth of water table: $0.5-3 \mathrm{~m}$
}

for the regional socioeconomic development, forest coverage fell from $17 \%$ in 1950 s to $13 \% 1980$ s, wetland area reduced more than $40 \%$ with land transition, averagely decreased 1469 ha annually among 1950-1985. With forest felling, soil erosion got worsen, and farm ecosystem was damaged. While wetland reduced, buffer zone disappeared, and pollutants went into rivers \& lakes directly. Consequently the eco-environment has been drastically deteriorated. In the period of 1981-2000, TP in- creased $25.0 \%$ annually in the Lake, TN was $11.7 \%$, and COD was $4 \%-6 \%$. From 80 's in last century, the water quality of Taihu Lake has descended one grade every 10 years, and now, it has become a typical area where is lacking qualified water [4]. According to Chinese General Station of Water Environmental Monitoring, water quality state was shown as Table 2 .

Although the government attached importance to the water pollution treatment and takes many measures, 
Table 2. Water quality state in Taihu (August 17-23).

\begin{tabular}{|c|c|c|c|c|c|}
\hline Location & Profile & $\mathrm{pH} \underset{(\mathrm{mg} / \mathrm{l})}{\mathrm{DO}}$ & $\begin{array}{r}\text { COD } \\
(\mathrm{mg} / \mathrm{l})\end{array}$ & $\begin{array}{l}\text { NH3-N } \\
(\mathrm{mg} / \mathrm{l})\end{array}$ & $\begin{array}{c}\text { Water quality } \\
\text { grading }\end{array}$ \\
\hline Shazhu, Wuxi & $\begin{array}{l}\text { Lake } \\
\text { body }\end{array}$ & 8.146 .46 & 2.80 & 0.28 & II \\
\hline $\begin{array}{c}\text { Lanshanzui, } \\
\text { Yixing }\end{array}$ & $\begin{array}{l}\text { Lake } \\
\text { body }\end{array}$ & 8.236 .52 & 3.70 & 0.30 & II \\
\hline Xishan, Suzhou & $\begin{array}{l}\text { Lake } \\
\text { body }\end{array}$ & 7.444 .69 & 4.90 & 0.23 & IV \\
\hline
\end{tabular}

mainly focusing on point source pollution such as industrial waste water decontaminating, lake water clearing, and the water quality of Taihu Lake was still exasperate and the situation of water pollution was still austere. Especially the affair of blue-green algae bloom occurred in May 2007 sounded the alarm for the people and the government. It was really recognized that the risk and hazards of eutrophication. Therefore much more attempts should be put into the struggle. No doubt, the function of forests was significant in controlling non-point source agricultural pollution (NPP) in Taihu Lake basin.

\section{Analysis on Source and Sink of Non-Point Agricultural Pollution}

\subsection{Framework of Source and Sink of NPP}

For Taihu Lake basin the inflowing water comes mainly from mountains to the west and southwest of the lake, while the draining rivers start mostly from the east coast of the lake. Several rivers and channels connect the lake with Changjiang, but the water flux is controlled by dams to maintain the lake water level within a range of fluctuation of 2-3 $\mathrm{m}$ [1].

According to the source-sink theory, here source means inputs of pollutants, and sink indicates outputs of pollutants. In this basin source-sink of non-point agricultural pollution could be described as Figure 1 .

It could be concluded from Figure 1 that the causes of water body pollution and eutrophication problem were complicated and multiple.

\subsection{Components of the Source}

According to the framework of source-sink of NPP as Figure 1 shown, the major agricultural NPP that resulting from these activities were acidy rain, livestock manure, fertilizers \& pesticides, rubbishes \& garbage. For these sources, to some extent acidy rain naturally occurred, while the others were concerned with human activities.

Located upstream of the Lake basin, Xitiaoxi river and Dongtiaoxi river both lied in Zhejiang province are recognized as the headwaters of the Lake. In the region local people live on the mountain range, planting bamboo and/or tea trees, cultivating grain or cash crops. During these farming activities, agrochemicals were applied, usually overused in order to have a good harvest and get much higher incomes. Moreover soils were often disturbed naturally. Thus when heavy raining or storm happening, water \& soil erosion had to occur, and these soil nutrients finally flowed into the Lake passing through linked waters [3].

In a word, with rapid development of industry and the excess consumption of pesticides for agriculture, large amount of pollutants and nutrients like nitrogen and phosphorus were drained into surrounding channels and finally into the Lake, these materials caused an overgrowth of algae and further deterioration, including oxygen depletion, which resulted in the severe pollution.

\subsection{Distribution of the Sink}

As Figure 1 shown that the nutrients leading to eutrophication could be uptaken and/or digested by aquatic animals such as plankton, fishes, shrimps, aquatic plants or riparian forests which were naturally grown or planted. Nowadays some fries such as grass carp, chub, etc. often are put in rivers, lakes and reservoirs to purify water. On the other hand, around the watershed usually wetlands were established including aquatic plants such as duckweeds, buttercup, water lily, which were harvested annually to reduce nutrition content in water bodies. Sometimes a certain woody species were chosen and planted such as Nyssa aquatica, Liquidambar styraciflua, Quercus nuttallii, Carya illinoinensis Koch, Phyllostachys nigra, etc.

Meanwhile the microbe played an important role to consume nutrients and prevent alga from blooming [5]. Some compounds and elements, especially heavy metals, sinked into river bed or lake bottom and became sediments.

\section{Function of Forests on NPP Controlling}

\subsection{Source Reduction}

As discussed above for NPP controlling forests functioned actually on both source reduction and sink expansion.

\subsubsection{Intercept Acidy Rain}

With industry development and urbanization speeding up, acidy rain occurred widely and frequently on the earth, hurt waters and soils as well as forests and understory plants, became one of the important sources of NPP [5,6].

When acidy rain fell on a forest, a complex process began. Firstly, the tree canopy sheltered and nullified the impact effect of raindrops, reducing the rain to a thin mist below the canopy, even in the most torrential showers. There was slight measurable silt loss from mature forests, exceeded by the creation of soils by forests. If the rain was light, little of it penetrated beyond the can- 
opy, but a film of water spread across the leaves and stems, and was trapped there by surface tension [7]. The cells of the tree absorbed what was needed, and the remainder evaporated to air.

In the stem bases of palms, plantains, and many epiphytes, or the flanged roots of figs, water was held as aerial ponds, often rich in algae and mosquitoes. Stem mosses and epiphytes absorbed many times their bulk of water, and the tree itself directed water via insloping branches and fissured bark to its tap roots, with spiders catching their share on webs, and fungi soaking up what they needed. Some trees trailed weeping branches to direct throughfall to their fibrous peripheral roots [8]. Through the interception of forests harmful effect of acidy rain on waters and soils were alleviated to some extent. In fact the degree of interception was most influenced by these factors: tree species, stand age, crown thickness, crown density, season, intensity of acidy rain, evaporation after rain [9].

\subsubsection{Reduce Water \& Soil Erosion}

It was widely understood that water flow from rain and irrigation, as well as, clean cultivation and vacant field borders could increase erosion potential. However forests provided a barrier that could slow water flow and trap soil particles [10]. In forested land below the humus lies the tree roots, each clothed in fungal hyphae and the gels secreted by bacterial colonies. $30-40 \%$ of the bulk of the tree itself lied in the soil; most of this extends over many hectares, with thousands of kilometers of root hairs lying mat-like in the upper $60 \mathrm{~cm}$ of soil (only $10-12 \%$ of the root mass lied below this depth but the remaining roots penetrate as much as $40 \mathrm{~m}$ into the rocks below). The root mat actively absorbed the solution that water had become, transporting it up the tree again to transpire to air. This was especially useful along waterways, especially in slop fields [11]. In the context, trees could be planned in combination with other practices in order to develop complete conservation systems that enhanced landscape aesthetics, improve water quality and provided wildlife habitat. Well planned forest shelterbelts retain water and reduce evaporation by blocking drying winds in summer.

\subsubsection{Decrease Chemical Fertilizer Application}

Intercropping is a feasible and practical land use system in the basin region. Through long-term practice, it was found that many trees could harmoniously grow together with crops in the same field and at the same time, of which some could fix nitrogen, e.g. leguminous trees, enrich the soil when their residues decompose [12]. Trees also improved the soil conditions in other ways. Leaf litter decomposed and added tilth as well as nutrients to the soil. Even the root system, with its rhizobia and related communities of organisms, released nutrients and improved soil structure when it decomposed. More- over some trees captured nutrients too deep in the soil for crops to reach, and brought these nutrients up to the surface and back to the soil as litter, where the crops could utilize them when the litter decomposed [13]. Furthermore, these deep roots could reduce the leaching of nutrients from soil following heavy rains and could conserve soil moisture by adding mulch and litters. By all the means, soil fertility could be maintained and generated naturally to help crops growing, less chemical fertilizers were applied to the fields [14].

\subsection{Sink Expansion}

As mentioned formerly there were different ways for pollutants output when eutrophication occurred in the water body. During the procedure of NPP combating constructing forested wetland and riparian forest buffer zone was significant for sink expansion.

\subsubsection{Construct Forested Wetlands}

The ecotones between lakes and terrestrial ecosystems were crucial for protection of the lake ecosystem against anthropogenic impact [15]. In view of the situation faced in Taihu Lake basin: population growing fast, surrounding lands mostly using for agriculture, construction of artificial wetlands was an attractive and cost-moderate solution to pollution by diffuse sources and even wastewater.

As Table 3 indicated, compared with the other type of wetland, forested wetlands were able to cope with the nitrogen and heavy metal pollution from these sources. It prevented, to a certain extent, penetration of undesirable components into the lake and protected the most vulnerable ecosystems, which were often lakes and reservoirs. The denitrification potential of wetlands was often surprisingly high. As much as 2,000 to $3,000 \mathrm{~kg}$ of nitrate-nitrogen could be denitrified per hectare of wetlands per year, depending on the hydraulic conditions [16]. This was of great importance for the protection of lakes, because a significant amount of nitrate was released by agricultural activities. As much as $100 \mathrm{~kg}$ nitrate-nitrogen per hectare may be found in the drainage water from intensive agriculture.

It was essential to properly plan where to place the forested wetlands, as their effects were dependent on the hydrology (i.e., they should be covered by water most of the year and had a sufficient retention time to allow them to solve the considered and specific pollution problems), and on the landscape pattern.

As Jinlin Chen (2002) [17] did, the effect of forest on water environment protection was vital. When the width ratio of farmland to forest belt was 100 to 40 , the purification effect on the losing nutrients was the best and $50.05 \%$ losing N, 29.37\% losing P could be absorbed by forest under rape-rice rotation and $30.98 \% \mathrm{~N}, 86.73 \% \mathrm{P}$ could be absorbed by forest under wheat-rice rotation. 
Table 3. Characteristics of different type of wetlands adjacent to lakes.

\begin{tabular}{ccc}
\hline $\begin{array}{c}\text { Type of } \\
\text { wetland }\end{array}$ & Characteristics & Ability to retain diffuse pollutants \\
\hline $\begin{array}{c}\text { Wet meadows } \\
\begin{array}{c}\text { Fresh water } \\
\text { marshes }\end{array}\end{array}$ & $\begin{array}{c}\text { Grassland with waterlogged soil. Standing water } \\
\text { for a part of the year. }\end{array}$ & $\begin{array}{c}\text { Denitrification only in standing water. Removal of nitrogen and phosphorus } \\
\text { by harvest. }\end{array}$ \\
$\begin{array}{c}\text { Forested } \\
\text { wetlands }\end{array}$ & $\begin{array}{c}\text { Reed-grass dominated, often with peat } \\
\text { accumulation. }\end{array}$ & High potential for denitrification, which is limited by the hydraulic \\
conductivity. \\
\end{tabular}

Under this circumstance the purifying ability of water is very satisfactory. When the width ratio of farmland to forest belt was 150 to $40,33.37 \%$ lost N, $19.58 \%$ lost $\mathrm{P}$ could be absorbed by the forest under rape-rice rotation, while under wheat-rice rotation $20.65 \%$ lost $\mathrm{N}$ and 57.82 $\%$ lost $\mathrm{P}$ could be absorbed. There was only some purification effect when the width ratio of farmland to forest belt was 200 to 40 . According to the analysis, it was suitable when the width ratio of farmland to forest between 100 to 40 and 150 to 40, because it not only could purify water, but also occupy less farmland.

For species selection, besides trees such as Nyssa aquatica, Liquidambar styraciflua, Quercus nuttallii, the following emergent macrophyte species were proposed to be used in constructed forested wetlands: cattails, bulrush, reeds, rushes, papyrus, and sedges. Submerged species could be applied in deep-water zones [3]. Species that had been used for this purpose include coon tail or horn wart, redhead grass, widegeon grass, wild celery, and water milfoil.

\subsubsection{Establish Riparian Forest Buffers}

Generally speaking, riparian forest buffers were typically a band of trees, shrubs, herbaceous cover or grasses with a certain width along a stream bank. Such a band of vegetation could trap sediment and bacteria, and absorb nutrients from both polluted runoff and sub-surface flow.

Riparian forest buffers were typically on sites with fine soils because of their position on the landscape [5]. So that the riparian forest buffer design needed to not only provide environmental protection but also economic benefits such as mid to long-term products as farmers rely on the fields to live. For example some of the products that could be harvested following the end of the conservation incentives at age 10 or 15 ; included decorative woody floras or short rotation crops for fuel, fodder or paper pulp.

Certain combinations of trees, shrubs, and grasses could function effectively as nutrient and sediment sinked for NPP pollutants [17]. As a special land use system, the woodlot must be intentionally integrated with crops and/or livestock. It was ideal if the woodlot management included active management of both the overstory trees and some type of understory crop simultaneously to produce non-timber products. This was not just wild harvesting of some understory plants such as mushrooms, but was a very intentional management system. Many high-value non-timber forest crops e.g., ginseng, goldenseal, mushrooms, and decorative ferns were cultivated under the protection of a forest canopy that had been modified to provide appropriate microclimate and light conditions [13]. Meanwhile, the timber stand improvement activities were carried out to develop the appropriate understory conditions. For Example, thinning less desirable stems and pruning lower branches on the eventual crop trees could result in the production of clean, knot-free wood that would eventually bring a higher economic return [12].

Hence streamside buffer strips were an effective best management practice that would help make the agricultural landscape sustainable, and reduce non-point source inputs into surface waters, which in turn should produce improvements in surface water quality, aquatic habitat, and aquatic communities [18].

It was concluded that similar buffer strips should be established along both sides of any perennial or intermit tent stream, as well as around lakes and ponds in and near farming activities, to reduce the adverse effects of NPP on surface water quality and aquatic life.

\section{Conclusions and Discussions}

Located at the center of Changjiang delta region, the Taihu Lake and its effluent rivers are important sources of water for the inhabitants and rapidly increasing industrial factories in Shanghai, Wuxi, Suzhou and other neighboring cities, so that the pollution of the Lake is a serious social concern.

The pollutants originated mainly from acidy rain, home sewage of the vast number of inhabitants, livestock manure, agricultural fertilizers \& pesticides applied over fields in the drainage basin, and the industrial sewage of more than 700 factories and mines. Due to the kinds of pollutants, the Lake water was getting highly eutrophic, with frequent blooms of blue-green algae even in early summer or late autumn annually. Compared with pointsource pollutants, diffuse pollution was much complicated and difficult to control. Thus combating NPP was paid much great attention.

Based on analysis on source-sink of NPP in Taihu Lake basin, it was concluded that the function of forests on NPP control was multiple and significant. 
In view of the fact in the area: more population, less land, approaching reasonable land use system was crucial to maintain regional socioeconomic sustainable development. It was proved intercropping was favorable for controlling soil erosion, increasing soil fertility and gaining higher benefit of the slope field by relatively low input [19]. Besides of this art, building riparian forest buffers along rivers around Taihu Lake also was significant to tackle agricultural NPS pollution in headwater region.

Widely applied forested wetlands had acted mainly as sources of a variety of wood and non-wood products, in addition to a kind of landscape. At present, the importance of wetlands for agricultural sustainability and environmental protection was becoming increasingly emphasized.

\section{Acknowledgement}

This research is one part of Jiangsu provincial Key Scientific \& Technological Project (BE2009603 and BE2008636), National Scientific \& Technological Project (No.2006BAD03A15), RISF6803 and AusAID project "Capacity building for riverhead forest conservation and integrated water resource management in China". We are grateful to all the supports.

\section{References}

[1] B. Q. Qin, "Hydrodynamics on Lake Taihu, China," Ambio, Vol. 26, No. 8, pp. 45-48, 1999.

[2] S. W. Chai, X. M. Pei, Y. L. Zhang, J. H. Li, and J. F. Zhao, "Research on agricultural diffuse pollution and controlling technology," Journal of Soil and Water Conservation, Vol. 20, No. 6, pp. 191-194, 2006.

[3] J. F. Zhang, M. Y. Fang, and S. Li, "Developing agroforestry in slopelands to combat non-point pollution in China," Chinese Forestry Science and Technology, Vol. 6, No. 4, pp. 67-72, 2007a.

[4] J. F. Zhang, "Agroforestry and its application in amelioration of saline soils in eastern China coastal region," Forestry Study in China, Vol. 6, No. 2, pp. 27-33, 2004.

[5] T. C. Daniel, A. N. Sharpley, and J. L. Lemunyou, "Agricultural phosphorus and eutrophication: A symposium overview," Journal of Environmental Quality, Vol. 27, No. 1, pp. 251-257, 1998.

[6] C, Gao, "Environmental management options practiced in Europe to mitigate agricultural nutrient pollution of ground and surface water," Agricultural Eco-environment, Vol. 51, No. 2, pp. 50-53, 1999.

[7] M. A. Altieri, "The ecological role of biodiversity in agroecosystems," Agriculture, Ecosystems and Environ- ment, No. 74, pp. 19-31, 1999.

[8] J. Baudry, R. G. H. Bunce, and F. Burel, "Hedgerows: An international perspective on their origin, function and management," Journal of Environmental Management, No. 60, pp. 7-22, 2000.

[9] B. Deckers, M. Hermy, and B. Muys, "Factors affecting plant species composition of hedgerows: Relative importance and hierarchy," Acta Oecologica, No. 26, pp. 23-37, 2004.

[10] J. R. Archer and M. J. Marks, "Control of nutrient losses to water from agriculture in Europe," Proceeding of Fertilizer Society, Vol. 6, No. 5, pp. 405-409, 1997.

[11] J. F. Zhang and Q. X. Sun, "Review on agroforestry systems in China," Chinese Forestry Science and Technology, Vol. 4, No. 3, pp. 80-84, 2005.

[12] W. L. Zhang, S. X. Wu, H. J. Ji, and H. Kolbe, "Estimation of agricultural non-point source pollution in China and the alleviating strategies I: Estimation of agricultural non-point source pollution in China in early 21 century," Chinese Science of Agriculture, Vol. 37, No. 7, pp. 1008-1017, 2004.

[13] R. C. Schultz, “Agroforestry opportunities for the United States of America," Agroforestry Systems, No. 31, pp. 117-132, 1995.

[14] J. F. Zhang and G. H. Qin, "Poplar-based agro-forestry in China and its economic analysis," Shandong Science and Technology Press, 2007b.

[15] R. A. Young, "A non-point source pollution model for evaluating agricultural watershed," Journal of Soil and Water Conservation, Vol. 44, No. 2, pp. 168-173, 1989.

[16] J. L. Chen, L. L. Shi, and A. G. Zhang, "Controlling effects of forest belts on non-point source pollution of agricultural lands in Taihu Lake area, China," Journal of Forestry Research, Vol. 13, No. 3, pp. 213-216, 2002.

[17] S. de Blois, G. Domon, and A. Bouchard, "Factors affecting plant species distribution in hedgerows of southern Quebec," Biological Conservation, No. 105, pp. 355-367, 2002.

[18] D. Kleijn and M. Verbeek, "Factors affecting the species composition of arable field boundary vegetation," Journal of Applied Ecology, No. 37, pp. 256-266, 2000.

[19] A. G. Busck, "Hedgerow planting analyzed as a social system-Interaction between farmers and other actors in Denmark," Journal of Environmental Management, No. 68, pp. 161-171, 2003. 